\title{
ANALISIS SISTEM PENDAFTARAN PASIEN RAWAT JALAN DI PUSKESMAS KECAMATAN DUREN SAWIT JAKARTA TIMUR 2014
}

\author{
Berry Fether ${ }^{1}$, Diana Barsasella ${ }^{2}$ \\ ${ }^{1}$ Alumni Program Studi S1 Kesehatan Masyarakat STIKes Persada Husada Indonesia \\ ${ }^{2}$ Dosen Program Studi DIII PIKES Poltekkes Kemenkes Tasikmalaya \\ Email: ${ }^{1}$ b.fetherz@yahoo.com, ${ }^{2}$ barsasella@yahoo.com
}

\begin{abstract}
Health services are every efforts organised by individuals or groups simultaneously in an organisation to maintan and increase health, prevent and cure diseases and restore the health of individuals, families, groups and/or the community (Lovely and Loobam 1973, in Waluyo, 2008). Health management for the community on the basic level In Indonesia is through the public health centres. If the service provided is good then visitors will feel satisfied but when services fails to provide satisfaction leading to a decrease of visitors resulting in a negative image of the public health centre. Registration booth as one of the service point of early servicing given by public health centre officers to visitors also influences the level of service system given to the visitors. If the health system registration is good, the public health centre manajement will also be good and visitors will feel satisfied of the services rendered. The aim of this research is to find out about the outpatient registration service system. This is a qualitative research obtained through in-depth interviews, observation and documentations on 4 informants. Results of the research showed patients' registration service still not optimal caused by the various interlinking factors. However the service scope is good marked by an increase of patients. This research suggest a need to improve services related to various factors among others liked manpower, facilities and procedures.
\end{abstract}

Keywords : Outpatient Registration Services System

\begin{abstract}
Abstrak
Pelayanan kesehatan adalah setiap upaya yang diselenggarakan sendiri atau secara bersama-sama dalam suatu organisasi untuk memelihara dan meningkatkan kesehatan, mencegah dan menyembuhkan penyakit serta memulihkan kesehatan perorangan, keluarga kelompok dan ataupun masyarakat (Lovely dan Loobam 1973, dalam Waluyo, 2008). Penyelenggaraan kesehatan untuk masyaraakat ditingkat dasar di Indonesia adalah melalui Puskesmas. Jika pelayanan yang diberikan dengan baik maka pengunjung akan merasa puas dan ketika pelayanan kurang memuaskan sehingga akan mengurangi minat pengunjung kepuskesmas akan menjadi citra negative bagi puskesmas tersebut. Loket pendaftaran merupakan salah satu tempat pelayanan kepada pengunjung sebagai sumber awal pelayanan yang diberikan oleh petugas Puskesmas. Pelayanan loket juga berpegaruh pada tingkat sistem pelayanan yang diberikan kepada pengunjung. Jika sistem pelayanan pendaftaran baik, maka manajemen puskesmas baik dan pengunjung Puskesmas akan merasa puas terhadap pelayanan yang diberikan Puskesmas. Tujuan penelitian ini untuk mengetahui sistem pelayanan pendaftaran pasien rawat jalan. Penelitian ini adalah penelitian kualitatif yang didapatkan dengan metode wawancara mendalam, observasi dan pendokumentasian dengan jumlah informan sebanyak 4 orang. Hasil dari penelitian mendapatkan bahwa pelayanan pendaftaran pasien masih belum optimal yang disebabkan oleh berbagiai faktor yang saling terkait namun cakupan pelayanan sudah baik ditandai dengan jumlah pasien yang meningkat. Hasil penelitian ini menyarankan bahwa perlu ada peningkat an pelayanan yang terkait dengan berbagi faktor diant aranya yaitu SDM, sarana dan prosedur.
\end{abstract}

Kata kunci : Sistem Pelayanan Pendaftaran Pasien Rawat Jalan 


\section{PENDAHULUAN}

Pembangunan kesehatan di Indonesia adalah upaya yang bertujuan untuk meningkatkan kesadaran, kemauan dan kemampuan hidup sehat bagi setiap orang agar dapat mewujudkan derajat kesehatan yang setinggi-tingginya sebagai perwujutan kesejahteraan umum sebagaimanayang dimaksud dalam pembukaan Undang-Undang Dasar (Depkes RI, 2004).

Pembagunan kesehatan diarahkan untuk mempertinggi derajat kesehatan yang besar artinya bagi pengembangan dan pembinaan sumber daya manusia Indonesia dan sebagai modal pelaksanaan pembangunan yang pada hakikatnya adalah pembagunan manusia Indonesia seutuhnya dan pembagunan seluruh rakyat Indonesia. Keberhasilan pembangunan bidang kesehatan akan sangat tergantung dari manajemen nasional yang efisien dan efektif sehingga mampu meningkatkan derajat kesehatan masyarakat, mencari suatu keadaan sejahtera dari badan, jiwa dan sosial yang memungkinkan setiap individu hidup produktif secara sosial dan ekonomis (UU Kesehatan No.2, 1992).

Pembangunan kesehatan terutama ditujukan pada golongan masyarakat yang berpenghasilan rendah baik pedesaan maupun perkotaan. Perhatian khusus perlu diberikan kepada daerah terpencil, kelompok masyarakat terasing, daerah pemukiman baru termasuk daerah transmigrasi dan daerah perbatasan. Salah satu subsistem dalam Sistem Kesehatan Nasional (SKN) adalah subsistem Upaya Kesehatan. Subsistem upaya kesehatan menurut SKN adalah bentuk dan cara penyelenggaraan upaya kesehatan yang paripurna, terpadu dan berkualitas, meliputi upaya peningkatan, pencegahan, pengobatan dan pemulihan, yang diselenggarakan guna menjamin tercapainya derajat kesehatan masyarakat yang setinggi-tingginya. Terdapat tiga tingkatan upaya kesehatan yaitu upaya kesehatan primer, upaya kesehatan sekunder, dan kesehatan tersier. Pusat kesehatan masyarakat atau Puskesmas termasuk sebagai sarana penyelenggara upaya kesehatan primer yaitu upaya kesehatan dimana terjadi kontak pertama masyarakat dengan pelayanan kesehatan (Hartono, 2010, p.30).

Lovely dan Loobam (1973) dalam penelitian Melisa (2012, p. 1) menyatakan pelayanan kesehatan adalah setiap upaya yang diselenggarakan sendiri atau secara bersama-sama dalam suatu organisasi untuk memelihara dan meningkatkan kesehatan, mencegah dan menyembuhkan penyakit serta memulihkan kesehat an perorangan, keluarga, kelompok ataupun masyarakat.

Penyelenggaraan pelayanan kesehatan untuk masyarakat di tingkat dasar di Indonesia adalah melalui puskesmas, dimana puskesmas sebagai ujung tombak pelayanan dan pembangunan kesehatan, yang merupakan salah satu unit organisasi fungsional Dinas Kesehat an Kabupaten/Kotamadya dan diberi tanggung jawab sebagai pengelola kesehatan bagi masyarakat tiap wilayah kecamatan dari kabupaten/ kotamadya bersangkutan (Hartono, 2010, p. 31).

Lubis (1993) dalam penelitian Irma Journalize (2002, p. 1) menyatakan pemerataan pelayanan kesehatan merupakan aspek penting yang harus dipenuhi dalam mempercepat tercapainya tujuan pembagunan nasional di bidang kesehatan, dilihat dari aspek distribusi, kepadatan penduduk, kondisi geografis dan luas wilayah. Pengertian pelayanan kesehatan yang dimaksud selayaknya mengandung aspek fisik meratanya pelayanan (availability) akan tetapi secara luas juga memiliki keterjangkauan (accessibilitay) dari segi jarak ekonomi dan budaya serta mutu (quality) dari pelayanan itu sendiri.

Pelayanan kesehatan di puskesmas merupakan kegiatan menyeluruh yang meliputi kegiatan promotif, preventif, dan kuratif yang dilaksanakan secara terpadu, dengan program yang dilaksanakan secara terntegrasi dibawah koordinasi pimpinan puskesmas, untuk dapat terselengaranya kegiatan yang terencana dan terprogram dengan baik.

Sistem pelayanan yang telah ditetapkan di puskesmas kepada setiap pasien yang datang ke puskesmas adalah memberikan pelayanan pemeriksaan yang baik pada setiap pengunjung yang datang untuk memeriksakan diri ataupun berobat sehingga memberikan kesan yang akrab dan nyaman serta tidak menimbulkan rasa kekhawatiran terhadap penyakit yang diderita serta berusaha memberikan pengobatan yang terbaik terhadap penyakit pasien, memberi pelayanan secara tepat dan cepat kepada setiap pengunjung puskesmas. Dengan adanya bentuk pelayanan kesehatan yang diberikan oleh puskesmas ini, diharapkan pengunjung akan dapat memberikan penilaian tersendiri terhadap puskesmas tersebut. Jika pelayanan yang diberikan sesuai dengan yang dikehendaki, maka pengunjung akan puas, jika yang terjadi sebaliknya maka akan menyebabkan kehilangan minat pengunjung untuk berobat dan ini akan menyebabkan pengunjung puskesmas mempunyai pandagan negatif terhadap puskesmas tersebut yang akan mengakibatkan menurunya jumlah pengunjung puskesmas. 
Salah satu tempat pelayanan petugas yang diberikan puskesmas di loket pendaftaran yaitu memberikan nomor antrian atau memberikan kartu rawat jalan yang sudah terdaftar sebelumnya. Pelayanan rawat jalan merupakan salah satu tempat pelayanan puskesmas kepada pengunjung, di mana pelayanan pendaftaran rawat jalan Puskesmas merupakan awal tempat untuk pasien mendapatkan pelayanan berobat yang diberikan oleh petugas puskesmas.

Berdasarkan studi awal yang peneliti lakukan di Puskesmas Duren Sawit bahwa terdapat pelayanan agak lambat pada pendaftaran pasien rawat jalan. Kemudian pasien yang sudah mendapatkan karcis pendaftaran kunjungan, dipanggil tidak berurutan sesuai dengan nomor yang tertera pada karcis. Ada beberapa pasien dengan nomor lebih kecil dipanggil belakangan, sehingga memicu keresahan pasien. Dari latar bakang diatas peneliti tertarik untuk melakukan penelitian pelayanan publik dengan judul "Analisis Sistem Pendaftaran Pasien Rawat Jalan di Puskesmas Kecamatan Duren Sawit Jakarta Timur Tahun 2014”.

\section{METODE}

\section{Fokus Penelitian}

Dalam menerapkan dan menganalisis sistem pendaftaran pasien rawat jalan di Puskesmas Duren Sawit, maka akan dilakukan kajian untuk mengetahui kendala-kendala yang menghambat Puskesmas dalam melakukan pelayanan pendaftaran, agar dapat mencapai tujuan pelayanan kesehatan yang baik, berdasarkan tinjauan pustaka, konsep dasar dan pemaparan teori, maka peneliti membuat fokus penelitian sebagai berikut berikut:

\section{INPUT}

\begin{tabular}{|l|l|l|}
\hline $\begin{array}{l}\text { - Tenaga } \\
\text { bagian } \\
\text { pendaftaran } \\
\text { - Metode yang } \\
\text { diterapkan } \\
\text { - Sarana } \\
\text { fasilitas } \\
\text { perlengkapan }\end{array}$ & $\begin{array}{l}\text { Serangkaian } \\
\text { kegiatan yang } \\
\text { terjadi di } \\
\text { bagian } \\
\text { pendaftaran } \\
\text { mulai dari } \\
\text { pengambilan } \\
\text { nomor antrian } \\
\text { sampai buku } \\
\text { status } \\
\text { pencatatan } \\
\text { medis pasien } \\
\text { diditrisbusikan } \\
\text { (Alur } \\
\text { Pendaftaran } \\
\text { Pasien) } \\
\text { sudah } \\
\text { terdaftar dan } \\
\text { siap } \\
\text { mendapatkan } \\
\text { pelayanan } \\
\text { dari } \\
\text { puskesmas }\end{array}$ \\
\hline \\
\hline
\end{tabular}

\section{Jenis Penelitian}

Jenis penelitian ini merupakan penelitian yang bersifat kualitatif dengan rancangan penelitian yang digunakan adalah studi kasus. Penelitian kualitatif ini memungkinkan untuk mendapatkan hal-hal yang tersirat (insight) dan merupakan jenis penelitian formatif yang secara khusus memberikan teknik untuk memperoleh jawaban atau informasi mendalam tentang pendapat atau perasaan seseorang atas fenomena yang sedang terjadi (Sumantri, 2011).

Studi kasus adalah studi yang mengeksplorasi suatu masalah dengan batasan masalah yang terperinci,memiliki pengambilan data yang mendalam, dan menyeratkan berbagai macam informasi. Dalam penelitian ini data yang yang dikumpulkan dan dinyatakan dalam bentuk katakata,kata-kata disusun dalam kalimat,misalnya kalimat hasil wawancara antara peneliti dengan informan (Sukmadinata, 2006).

\section{Informan Penelitian}

Informan adalah orang yang diajak untuk diwawancarai, diobservasi, diminta memberikan data, pendapat pemikiran dan persepsinya. Dalam penelitian ini yang menjadi subjek penelitian adalah petugas kesehatan di Puskesmas Duren Sawit.

Informan pada penelitian ini adalah

1. Petugas loket Pendaftaran Pasien (2 orang) inisial " $T$ " selaku informan kunci yaitu koordinator loket pendaftaran dan "I" merupakan petugas staff loket pendaftaran.

2. Pasien rawat jalan ( 2 orang) inisial " $Z$ " dan " $A$ " merupakan informan pendukung.

Informasi yang diperoleh mempunyai keterkaitan dengan manajemen pelayanan rawat jalan. Pemilihan sampel dilakukan sesuai dengan prinsip-perinsip yang berlaku dalam penelitian kualitatif yaitu:

a. Kesesuaian (appropriateness) yaitu sampel dipilih berdasarkan pengetahuan yang dimiliki berkaitan dengan topik penelitian.

b. Kecukupan (adequency) yaitu data yang diperoleh dari sampel seharusnya dapat menggambarkan seluruh fenomena yang berkaitan dengan topik penelitian. 


\section{HASIL DAN PEMBAHASAN}

\section{Input}

\section{Sumber Daya Manusia}

SDM adalah semua orang/pegawai yang terlibat di dalam pelayanan pasien rawat jalan, di pendaftaran pasien Puskesmas Kecamatan Duren Sawit di setiap tahapan mulai dari tahap penerimaan, pelayanan rawat jalan dan adminitrasi.

Jumlah SDM di unit pendaftaran pelayanan rawat jalan seluruhnya berjumlah 5 orang, mereka juga terlibat di ruang rekam medik. Semua petugas yang ada di unit tersebut sudah memiliki tugas masing-masing dan tidak saling berketergant ungan dengan petugas lainnya. Loket pendaftaran dibuka mulai pukul 07.30-12.00 WIB, kemudian istrahat, dan jam 13.00-16.00 WIB. Jadi semua petugas sudah mengerti apa yang harus dilaksanakan selama pelayanan pendaftaran rawat jalan untuk pasien seperti pada kutipan wawancara sebagai berikut:

"Yang bertugas mengurusi pelayanan pendaftaran pasien kita ada 5 orang, sudah masing-masing dengan tugas bagiannya sendiri”. (Unit Pendaftaran Pasien )

Tabel 1 Komposisi Pegawai Loket Pendaftaran

\begin{tabular}{ccccl}
\hline No & Jabatan & $\begin{array}{c}\text { Jenis } \\
\text { Kelamin }\end{array}$ & $\begin{array}{c}\text { Masa } \\
\text { Kerja }\end{array}$ & Pendidikan \\
\hline 1 & $\begin{array}{l}\text { Koordinator } \\
\text { Loket }\end{array}$ & Perempuan & 15 Tahun & SMA \\
2 & Staf Loket & Perempuan & 10 Tahun & SMA \\
3 & Staf Loket & Perempuan & 10 Tahun & SMA \\
4 & Staf Loket & Laki-laki & 8 Tahun & SMA \\
5 & Staf Loket & Perempuan & 2 Tahun & SMA \\
\hline
\end{tabular}

Sumber: Puskesmas Duren Sawit

Dalam menangani pelayanan pendaftaran pasien akan terdapat permasalahan atau beban disebabkan adannya pasien yang kurang mengerti tata cara pendaftaran, sehinga akan memakan waktu dalam menjelaskan dan menyebabkan pegawai menjadi lambat dalam melayani pasien lainnya. Namun bila pegawai tidak dapat membantu, maka pegawai meminta bantuan pegawai lain terutama di saat pasien sedang banyak berkunjung. Hal tersebut diungkapkan oleh informan " $T$ " sebagaimana dikutip pada wawancara berikut:

"Ada, pada saat pasien baru mau memulai mengisi pendaftran pasien, kita meski harus jelasin dulu untuk mengisi formulir pendaftaran agar mendapatkan nomor panggilan dan mengarahkan ke poli yang akan dituju."(Koordinator Loket)

Informan lainnya di bagian pelayanan pendaftaran pasien rawat jalan merasa tidak ada beban dalam bekerja, karena sudah sesuai dengan tupoksi. Tidak ada pegawai yang tidak bekerja dalam menangani pendaftaran pasien rawat jalan. Bila terdapat kesalahan data maka petugas akan kesulitan dalam mengurus data pasien yang berikutnya, karena pasien yang dilayani sangat banyak. Hal tersebut sebagaimana diungkapkan oleh informan "I" dikutip pada wawancara berikut:

"Oh ngak! kita sudah sesuai tempat, ada ditempat pendaftaran 1, ngentri 1, dibelakang sudah petugas yang sama, maka data pasien yang kita tangani agar tidak menjadi kesalahan dalam pencatatan data pasien". (Staf Loket)

Di dalam melaksanakan tugas semua kegiatan yang dilaksanakan membutuhkan adanya kerja sama di dalam suatu tim atau organisasi untuk mencapai tujuan yang sudah ditargetkan dan memperoleh keharmonisasian dalam bekerja. Semua pegawai di bagian loket pendaftaran sudah memehami dan mengerti dengan pekerjaan mereka masing-masing, semua data pasien diproses cepat untuk diserahkan ke poli-poli yang dituju. Hal tersebut sebagaimana diungkapan oleh Informan " $T$ " dikutip dalam wawancara berikut:

"Kita kerja sama dari mengentri data, pengisisan status dan pencat atan status, kita juga punya progam tugas masing-masing untuk mencari data pasien nanti untuk diantar ke poli masing-masing yang dituju".

Demikian juga yang yang dipaparkan oleh petugas lain yang menagani bagian pendaftaran pasien di Puskesmas Kecamatan Duren Sawit. Apa yang dijelaskan oleh informan " $T$ " yang mengenai mekanisme kerja sama di bagian pendaftaran pasien, demikian juga informan "I" menjelaskan hal yang sama. Hal tersebut sebagaimana diungkapkan oleh informan "I" dikutip dalam wawancara berikut:

" Masing-masing ada tugas, yang mencatat kartu status pasien, yang mengentri data dan yang bagian pendaftran".

Semua sesuatu hal yang dihadapi semua orang selau ada halangan atau kendala yang dialami,sebagai 
mana kendala yang dialami petugas pendaftaran pasien diPuskesmas Kecamatan Duren Sawit, kadang didapatkan pasien yang tidak membawa kartu berobat jadi masalah bagi pegawai untuk memproses data pasien dengan lengkap,akan tetapi pasien mengetahui alamat sesuai waktu berobat sebelumnya,petugas akan mudah untuk memproses data pasien. Hal tersebut sebagimana diungkpan oleh informan " $T$ " dikutip dalam wawancara berikut:

"kendalanya pasien tidak membawa kartu berobat,asalkan pasiennya tahu alamat dia sesuai waktu berobat".

Selain itu informan "I" di bagian pelayanan pendaftaran mengatakan bila ada pegawai yang cuti, mengakibatnya sedikit pekerjaan menjadi sedikit terhambat. Proses mengentri data menjadi lama dikarenakan kekurangan pegawai yang bertugas dalam pelayanan pendaftaran pasien, sehingga pegawai merangkap dua tugas dalam menyelesaikan pendaftaran pasien. Namun bila semua pegawai masuk semua akan mempercepat dalam mengentri data pasien. Hal tersebut sebagimana diungkapkan oleh informan "I" dikutip dalam wawancara berikut:

"Bila ada petugas yang cuti, paling entri datanya jadi lama, kalau lengkap semua ngak jadi masalah".

Menurut Handoko (2003), sumber daya yang penting dalam suatu organisasi adalah SDM, yang mana merupakan orang-orang yang memberikan tenaga, bakat, kreativitas, dan usaha mereka kepada organisasi. Unsur manusia merupakan faktor kunci penentu sukses atau gagalnya pencapaian tujuan organisasi.

Hal ini sesuai dengan ungkapan Yuli Uswantan Khasanah dalam penelitian yang berjudul Perencanaan Sistem Rekam Medis Berdasarkan Input dan Proses di Tempat Pendaftaran Pasien Rawat jalan Puskesmas Baguntapan II Kab. Bantul Tahun 2011. Man atau SDM sangat mempergaruhi sistem kerja rekam medis di pendaftaran pasien, tanpa adanya man atau SDM maka semua kegiatan pelayan pendaftaran pasien tidak akan berjalan secara semestinya.

\section{Sarana}

Sarana adalah peralatan dan ruangan yang dipergunakan dalam pelaksanaan kegiatan pendaftaran pasien rawat jalan. Kelengkapan sarana dan fasilitas pendukung dalam kegiatan kerja mendukung optimalisasi keberhasilan dari suatu aktifitas kerja. Pada ruang pelayanan pendaftaran pasien sarana yang ada sudah cukup memadai bagi pegawai yang ada di ruang pendaftaran pasien. Segala kegiatan yang dilakukan berhubungan dengan data pasien, dengan adanya sarana yang cukup memadai sangat mendukung bagi pegawai loket pendaftaran. Hal tersebut sebagimana diungkapkan oleh informan " $T$ " dikutip dalam wawancara berikut:

"iya sudah cukup memadai, jadi sangat mendukung petugas dalam memproses data pasien"..

Hal serupa tersebut sebagaimana diungkapkan oleh informan "I" dikutip dalam wawancara berikut:

\section{"Memadai"}

Pada bagian pelayanan pendaftaran adminitrasi pasien, ruangan dalam pelayanan masih kurang memadai sehingga menjadi suatu hambatan dalam pelayanan pendaftaran pasien, terlebih jika banyak pasien yang berkunjung ke Puskesmas. Ruangan yang sempit menyebabkan banyak pasien harus berdiri dalam mengantri, tidak mendapat tempat duduk, hal tersebut sebagimana diungkapkan oleh informan " $\mathrm{T}$ " dikutip dalam wawancara berikut:

"Hambatanya ruangan yang masih sempit ,jadi masih banyak pasien yang tidak mendapatkan kursi untuk duduk pada saat mengantri menunggu nomor antian dipanggil, apa lagi pada waktu pasien lagi banyak waktu mau berobat, jadi masih banyak yang harus berdiri”.

Lain halnya dengan pernyataan informan "I" mengenai hambatan yang berhubungan dengan pendaftaran pasien. Menurut informan "I" tidak ada hambatan dengan sarana atau fasilitas yang ada bagian pendaftaran pasien, yang menjadi hambatan adalah bila pegawainya bekurang atau cuti kerja, sehingga dalam memproses data pasien menjadi lambat tidak seperti waktu biasanya. Hal tersebut sebagimana diungkapkan oleh informan "I" dikutip dalam wawancara berikut:

"Ngak,ngak ada! tetapi bila pegawainya bekurang aja, kita kerjanya jadi tidak bisa cepat dalam melakukan pengentrian data pasien dengan tenaga yang kurang".

Berdasarkan observasi penulis, ruangan yang ada pada pelayanan pendaftaran pasien yang berada 
dilantai bawah (dasar) pintu masuk puskesmas, merupakan ruangan atau tempat pasien untuk pertama kali mendaftarkan identitas dan mengisi segala persyaratan yang berhubungan dengan pelayanan pendaftran pasien rawat jalan, di ruang loket pendaftaran pasien terdapat 4 tempat untuk pelayanan pasien rawat jalan, semua pegawai akan berada di tempat tersebut agar memperlancar proses pelayanan, tidak terjadi pengantrian lama, pasien harus membayar adminitrasi pendaftaran langsung di loket pendaftaran tersebut. Terdapat komputer, printer, meja, kursi, lemari dan fasilitas sarana lainya yang mendukung pelayanan pendaftaran pasien bagi pegawai loket pendaftaran, dan alur yang jelas dapat diketahui pasien seperti yang diungkapkan informan " $T$ " dikutip dalam wawancara berikut:

\section{"Mengerti, kita pemanggilan sesuai nomor antrian".}

Alur berfungsi untuk memudahkan pasien dalam melaksanakan pendaftaran. Semua data atau kartu status pasien akan disimpan dalam lemari, komputer sesuai nomor yang telah diberikan untuk memudahkan pegawai mengentri data pasien dan memudahkan pencarian data bila diperlukan oleh pasien dalam melakukan pelayanan sewaktu-waktu. Status pasien disimpan berdasarkan folder dimana didalam 1 folder terdapat 1 keluarga dengan sesuai nomor yang telah berikan, Hal tersebut sebagimana diungkapkan oleh informan "T" dan"I" dikutip dalam wawancara berikut:

\section{Informan "T"}

"lemari..!! "Sistem folder,sesuai nomor, dan di simpan 1 folder (1 keluarga)".

\section{Informan "I"}

"Dirak pake nomor urut atau lemari...!!" sistem nomor, komputer".

Pada bagian ini dijabarkan wawancara dengan informan kunci 1 inisial "T" dan informan kunci 2 inisial "I" mengenai komponen input yang terdiri dari tiga kriteria yaitu SDM, Sarana dan Metode. Kedua informan kunci merupakan petugas yang bertugas di loket pendaftaran pasien di Puskesmas Kecamatan Duren Sawit. Berikut matriks hasil wawancara dengan informan kunci menngenai komponen input untuk sistem pendaftaran pasien rawat jalan di Puskesmas Kecamatan Duren Sawit Jakarta Timur.
Tabel 2 Matriks Hasil Wawancara dengan Informan Kunci 1, Informan Kunci 2, Tentang Komponen Input Loket Pendaftaran Pasien di Puskesmas Kecamatan Duren Sawit Jakarta Timur

\begin{tabular}{|c|c|c|}
\hline $\begin{array}{l}\text { Komponen } \\
\text { INPUT }\end{array}$ & Informan 1 (T) & Informan 2 (I) \\
\hline $\begin{array}{l}\text { Sumber Daya } \\
\text { Manusia } \\
\text { (SDM) }\end{array}$ & $\begin{array}{ll}\text { - } & \text { Ada } 5 \text { (lima) } \\
\text { orang petugas } \\
\text { - } & \text { Bertugas } \\
\text { menjelaskan } \\
\text { pada pasien } \\
\text { baru mau } \\
\text { daftar (sesuai } \\
\text { beban kerja) }\end{array}$ & $\begin{array}{ll}\text { - } & \text { Ada } 5 \text { (lima) } \\
\text { orang petugas. } \\
\text { - } & \text { Pekerjaan } \\
& \text { sesuai tugas } \\
& \text { masing-masing }\end{array}$ \\
\hline Sarana & $\begin{array}{ll}\text { - } & \text { Sudah cukup } \\
\text { memadai } \\
\text { - } & \text { Ruangan } \\
\text { area loket } \\
\text { pendaftaran } \\
\text { sempit } \\
\text { - } & \text { Ada alur } \\
& \text { pelayanan } \\
\text { - } & \text { pasien } \\
\text { - } & \text { Memari } \\
\text { - } & \text { nomggunakan } \\
\text { - } & \text { Komputer } \\
\text { - } & \text { Printer }\end{array}$ & $\begin{array}{ll}\text { - } & \text { Sudah cukup } \\
\text { - } & \text { Ruangan } \\
& \text { area loket } \\
& \text { pendaftaran } \\
& \text { sempit } \\
\text { - } & \text { Ada alur } \\
& \text { pelayanan } \\
\text { - } & \text { pasien } \\
- & \text { Lemari } \\
- & \text { Pakai nomor } \\
- & \text { Komputer } \\
& \text { Printer }\end{array}$ \\
\hline Metode & 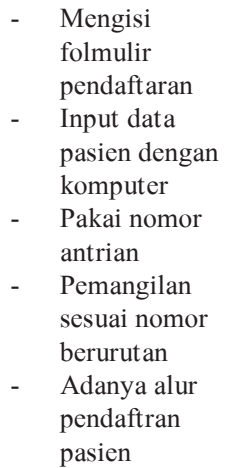 & $\begin{array}{ll}\text { - } & \text { Mengisi } \\
\text { formulir } \\
\text { pendaftaran } \\
\text { - } & \text { Persyaratan } \\
\text { pendaftaran } \\
\text { - } & \text { Pakai nomor } \\
\text { antrian } \\
\text { - } & \text { Pemangilan } \\
\text { sesuai nomor } \\
\text { berurutan }\end{array}$ \\
\hline
\end{tabular}

Hal ini sudah sesuai dengan pendapat menurut (Jacobalis Samsi 2005) yang menyatakan ketentuan mengenai sarana yang baik, penampilan fisik berpegaruh terhadap pelayanan psien, petugas pelayanan perlu meningkatkan penataan dan kerapian ruang pelayanan dalam mengatasi presepsi buruk dalam pelayanan kesehatan.

Hal ini sejalan dengan penelitian Yuli Uswantan Khasanah, dengan judul Perencanaan Sistem Rekam Medis Berdasarkan Input dan Proses di Tempat Pendaftaran Pasien Rawat Jalan Puskesmas Baguntapan II Kab. Bantul Tahun 2011. Penelitian ini menyatakan sarana dan ruang merupakan pendukung dalam kegiatan pelayanan perencanaan pelayanan kesehatan. 


\section{Proses}

\section{Pelayanan Awal Pasien}

Secara umum tidak ada pemisahan untuk penerimaan pasien dalam pelayanan pasien di Puskesmas Kecamatan Duren Sawit. Fungsi dan tugas pokok loket pendaftaran adalah sebagai unit sentral untuk pelayanan petugas puskesmas kepada pengunjung, dimana loket puskesmas merupakan awal mula pelayanan yang diberikan petugas puskesmas. Semuanya disatukan untuk diarahkan ke poli masing-masing, sebelum memulai pendaftaran pasien, petugas pendaftaran pasien terlebih dahulu menyiapkan formulir dan catatan rekam medis meliputi: Formulir pendaftaran (baru dan lama), KIB/KTPP (Kartu Indeks Berobat/Kartu Tanda Pengenal Pasien), Pulpen, Dokumen Rekam Medis (DRM) rawat jalan baru yang telah diberi nomor rekam medis, Buku Register Pendaftaran Pasien, Buku Catatan Penggunaan Nomor Rekam Medis dan Karcis Pendaftaran Pasien. Hal tersebut sebagimana diungkapkan oleh informan " $T$ " dikutip dalam wawancara berikut:

"Sebelum petugas membuka pelayanan pendaftaran pasien pukul 08.00, petugas terlebih dahulu mempersiapkan seperti: Formulir pendaftaran (baru dan lama), KIB/KTPP (Kartu Indeks Berobat/ Kartu Tanda Pengenal Pasien), Pulpen, Dokumen rekam medis rawat jalan baru yang telah diberi nomor rekam medis, Buku Register Pendaftaran Pasien, Buku Catatan Penggunaan Nomor Rekam Medis dan Karcis Pendaftaran Pasien". (Koordinator Pendaftaran Pasien)

Apabila pasien pertama kali melaksanakan pendaftaran di puskesmas, pasien harus mengisi formulir pendaftaran berwarna kuning untuk pasien lama dan formulir pendaftraan berwarna putih untuk pasien baru yang telah disedikan di loket pendaftaran guna untuk mendapatkan nomor antrian dan menunggu sebelum petugas memanggil nomor antrian pasien untuk dirujuk ke poli yang dituju. Pasien juga harus memberikan identitas diri apakah pasien sudah pernah berobat ke puskesmas tersebut atau belum pernah. Petugas akan menanyakan kartu berobat pasien untuk ditunjukkan ke petugas pendaftaran guna memudahkan adminitrasian pasien di bagian rekam medis. Setelah menyelesaikan pendaftaran pasien, petugas akan mengantarkan data pasien ke poli yang dituju untuk mendapatkan pelayanan perawatan medis. Waktu yang dibutuhkan petugas untuk mengantar berkas pasien ke poli yang dituju kurang lebih 15 menit setelah semua data di loket pendaftaran selesai direkap semua.

Dalam pelayanan pendaftaran pasien pasti ada alur prosedur yang jelas agar diketahui oleh pasien dan informasi yang jelas mengenai pelayanan pendaftaran pasien, akan tetapi dalam pelayanan pasien masih didapatkan pasien yang kurang mengerti dalam melaksanakan pendaftaran pasien sehingga petugas harus membantu. Apabila petugas tidak dapat membantu pasien, petugas minta bantuan pasien lain yang ada di ruangan pendaftaran untuk membantu pasien yang masih kurang mengerti tata cara pendaftaran pasien. Hal tersebut sebagimana diungkapkan oleh informan " $T$ " dikutip dalam wawancara berikut:

"Kalo pasiennya tidak bisa baca/menulis itu kita informasikan kepada pasien tersebut kita bantu dia, kalo kita lagi repot banget kita minta tolong sama orang lain, misal "tolong bu sama bapak siapa ?? gitu...!!! Karna kita tidak bisa bantu mereka". (Koordinator Pedaftaran Pasien)

Masalah dalam tahap pendaftaran pasien yang ditemukan oleh petugas ada pasien yang lupa membawa kartu berobat jadi petugas harus menyarankan kepada pasien untuk mendaftar lagi guna mendapatkan pelayanan dan nomor antrian. Hal tersebut sebagimana diungkapkan oleh informan " $T$ " dikutip dalam wawancara berikut:

"Pasien disarankan untuk mengisi formulir baru, agar mendapatkan nomor antrian seperti pasien yang lainnya”.(Koordinator Pedaftaran Pasien)

Setiap pasien yang sudah mendaftar akan dikenakan biaya sebesar Rp 2000 untuk poli umum, Rp 5000 untuk MTBS dan Rp 15000 untuk Dokter Umum, bagi pasien yang menggunakan kartu jaminan seperti kartu BPJS tidak dikenakan biaya untuk membayar uang pendaftaran, dan sebaliknya pasien yang tidak memiliki kartu BPJS akan dikenakan biaya pendaftaran. Uang pendaftaran akan diterima langsung oleh petugas pendaftaran dan disimpan dalam tempat khusus, selanjutnya uang pendaftaran akan diserahkan di kasir dan akan disimpan di bank. Uang yang disimpan di bank merupakan uang milik puskesmas untuk keperluan adminitrasi puskesmas berikutnya, seperti: membeli obat yang perlu dikeluarkan dana oleh puskesmas dan keperluan lain-lainnya. Hal tersebut sebagimana diungkapkan oleh informan " $T$ " dikutip dalam wawancara berikut: 
"Setiap pasien akan dikenakan biaya pendaftaran Rp 2000 untuk poli umum,Rp 5000 MTBS dan Rp 15000 dokter umum, apa bila pasien memiliki kartu jaminan BPJS maka tidak dikenakan biaya untuk pendaftaran, uang pendaftaran disimpan di tempat khusus dan nanti akan diserahkan ke kasir, selanjutnya disimpan dibank. Uang tersebut sudah milik puskesmas nanti dipergunakan untuk keperluan puskesmas seperti membeli obat-obatan dan keperluan lainnya”.

Hal ini sejalan dengan teori tentang kualitas Pelayanan menurut (Tjiptono 2005, p. 56) mencakup pengertian: kesesuaian dengan persyaratan, kecocokan untuk pemakaian, perbaikan berkelanjutan, bebas dari kerusakan/cacat, pemenuhan kebutuhan pelanggan sejak awal dan setiap saat, melakukan segala sesuatu secara benar dan sesuatu yang bisa membahagiakan pelanggan.

\section{Pendaftaran Pasien}

Pendaftaran Pasien adalah pelayanan yang diberikan kepada pasien yang masuk puskesmas untuk mendapatkan pelayanan medis untuk tujuan pengamatan, diagnosis, pengobatan, rehabilititasi dan pelayanan lainnya. Pasien akan didaftar secara detil oleh petugas dengan pengisian data yang lengkap oleh pasien. Setiap pasien pertama kali datang harus mendaftar di bagian pendaftaran untuk pengurusan administrasi pendaftaran dan pasien harus menunjukkan kartu identitas pasien bila pasien pernah berobat di puskesmas tersebut, maka pertama kali yang harus dilakukan pasien harus wajib mengisi kartu formulir pendaftaran, baik itu pasien lama atau pasien baru agar nantinya diberikan nomor antrian oleh petugas pendaftaran. Hal tersebut sebagimana diungkapkan oleh informan "I" dikutip dalam wawancara berikut:

"Pasien harus mengisi formulir pendaftaran, begitu juga bagi pasien baru atau lama untuk mendapatkan nomor antrian".

Semua data pasien akan dicatat oleh petuas pendaftaran .Pencatat identitas ke formulir rekam medis rawat jalan, data dasar pasien, KIB, KIUP, dan buku register pendaftaran pasien rawat jalan, pemberi dan pencatat nomor rekam medis sesuai dengan kebijakan penomoran yang ditetapkan. Penyedia dokumen rekam medis baru untuk pasien baru, Penyedia dokumen rekam medis lama untuk pasien lama melalui bagian filling, Penyimpan dan pengguna KIUP, Pendistribusi dokumen rekam medis untuk pelayanan rawat jalan. Data pasien tersebut akan disimpan dalam komputer sesuai nomor dan dalam satu folder keluarga yang telah dibuatkan oleh petugas pendaftaran pasien. Semua data akan dicatat setiap hari oleh petugas dan semua pencatatan data pasien dilakukan oleh semua petugas loket pendaftaran.

Pada setiap pendaftaran pasien selalu ada mekanisme pendaftaran sehinggamemudahkan pasien mengetahui bagimana mekanisme pendaftaran pasien dan alur pendaftaran. Namun peneliti mendapatkan informasi keterangan dari informan yang memaparkan bahwa alur pelayanan pendaftaran pasien tidak ada. Hal tersebut sebagimana diungkapkan oleh informan pendukung " $Z$ " dikutip dalam wawancara berikut:

"Mengetahui, daftar dulu diloket dan dikasih nomor antrian. Alur pendaftaran di puskesmas kayak nya kagak ada mas!!! Yang saya lihat banyak poster gitu mas....".

Setiap pasien yang sudah mendaftar di bagian pendaftaran pasien akan diberikan nomor antrian guna menunggu dipanggil untuk mendapatkan pelayanan medis dari poli yang akan dituju, Hal tersebut dikutip dalam wawancara oleh informan pendukung "Z" dikutip dalam wawancara berikut:

"Dikasih nomor antrian, kita disuruh menunggu oleh petugas untuk dipanggil kembali mendafatkan pelayanan medis".

Hambatan yang dialami pasien dalam proses pendaftaran yaitu waktu yang dibutuhkan untuk menunggu antrian berkisar 5 samapi 10 menit, Hal tersebut dikutip dalam wawancara oleh informan pendukung " $Z$ ” dikutip dalam wawancara berikut:

\section{"Antri menunggu 5-10 menit"}

Selama menjalani proses pendaftaran pasien, pasien harus mengantri menunggu nomor antrian dipanggil oleh petugas untuk mendapatkan pelayanan medis dari puskesmas. Apabila ada nomor yang dipanggil oleh petugas selama 10 menit, maka nomor antrian dilanjutkan ke nomor berikutnya. Hal tersebut dikutip dalam wawancara oleh informan pendukung "Z" dikutip dalam wawancara berikut:

"Iya sesuai nomor, kecuali tidak ada orangnya nomornya dilewati,kalo sudah lewat 10 menit". 
Dalam pelayanan pendaftaran pasien, waktu yang dibutuhkan untuk pengisisan formulir pendaftaran oleh pasien sekitar 10 menit, hal tersebut dikutip dalam wawancara oleh informan pendukung " $Z$ " dikutip dalam wawancara berikut:

"10 menit paling cepat, lambat karena isi formulir pendaftaran".

Dan dalam penyelesaian administrasi keuangan pendaftaran pasien, pasien harus membayar di loket pendaftaran sebesar Rp.5000 apabila pasien sudah menyelesaikan pengisian formulir pendaftaran pasien. Hal tersebut dikutip dalam wawancara oleh informan pendukung " $Z$ " dikutip dalam wawancara berikut:

“ Diloket pendaftaran,Rp 5000”.

Ada juga informan pendukung 2 yang memaparkan bahwa pada saat mengantri di loket pendaftaran lima nomor sekaligus dipanggil untuk menunggu didepan loket pendaftaran itu sesuai nomor yang berurutan. Hal tersebut dikutip dalam wawancara oleh informan pendukung "A" dikutip dalam wawancara berikut:

"Ya, paling kita menunggu nomor kita dipanggil sekitar 10menitlah lamanya, karena 5 berurutan nomor antrian dipanggil dulu, ngantri di depan loket".

Sebagai mana dijelaskan juga oleh informan pendukung 1 " $Z$ " menyatakan kekesalannya terhadap pelayanan petugas loket pendaftaran dalam pelayanan pendaftaran pasien, karena nomor yang dipanggil tidak berurutan atau dilompati, dan waktu menunggu lebih dari 10 menit. Hal tersebut dikutip dalam wawancara oleh informan pendukung " $Z$ " dikutip dalam wawancara berikut:

"Hambatan yang lain adalah, saya pernah kesel, karena ada pasien lain yang datang lebih belakangan dengan nomor urut di bawah saya ..eh...malah dipanggil duluan untuk pemeriksaan, gimana gak sebel saya....".

Selanjutnya informan menjelaskan, mengapa hal tersebut bisa terjadi dikarenakan kelalaian atau lamanya petugas mencari kartu status pasien di ruang rekam medik, sehingga kartu status pasien yang ditemukan terlebih dahulu yang diantarkan duluan ke bagian pemeriksaan atau poli tempat pelayanan kesehat an pasien. Sehingga kartu status yang duluan diantar, akan dipanggil duluan dan informan pernah menunggu ampai 5 jam untuk dipanggil. Hal tersebut dikutip dalam wawancara oleh informan pendukung "Z" dikutip dalam wawancara berikut:

"Sepertinya petugasnya lama mas nyari kartunya di belakang, jadi status pasien yang ketemu duluan itu yang dianter ke bagian pemeriksaan, yah itu akibatnya yang statusnya udah ada yang dipanggil duluan. Saya pernah nunggu dari jam 8 sampe jam 12 baru dipanggil."

Pendapat para ahli yang menyatakan teori pelayanan yang baik yaitu ketepatan waktu pelayanan, yang meliputi waktu tunggu dan waktu proses, akurasi pelayanan, yang meliputi bebas dari kesalahankesalahan, kesopanan dan keramahan dalam memberikan pelayanan, kemudahan mendapatkan pelayanan, misalnya banyaknya petugas yang melayani dan banyaknya fasilitas pendukung seperti komputer, Kenyamanan dalam memperoleh pelayanan, berkaitan dengan lokasi, ruang tempat pelayanan, ketersediaan informasi, dan lain-lain, Atribut pendukung pelayanan lainnya seperti ruang tunggu ber AC, kebersihan, dan lain-lain (Ratminto, 2005 :2), sedangkan menurut (Dwiyanto, $2005: 145$ ) bahwa kualitas pelayanan publik merupakan hasil interaksi dari berbagai aspek, yaitu sistem pelayanan, SDM pemberia pelayanan, strategi, dan pelanggan (customers).

\section{Adminitrasi}

Adminitrasi adalah proses administrasi dalam pengurusan kelengkapan persyaratan pendaftaran pasien dimulai dari pasien masuksampai pasien pulang.

\section{Pendaftaran Pasien}

Dalam pengadminitrasian pendaftaran pasien maka petugas mencatat, membukukan dan menyimpan semua data pasien didalam komputer dan disimpan di ruang rekam medik. Data pasien yang tersimpan akan digunakan oleh pasien bila berkunjung di puskesmas lagi untuk mendapatkan pelayanan medis berikutnya., sesuai dengan kutipan wawancara sebagai berikut:

“ iya itu memang tugas kita untuk melakukan pencatatan dan penyimpanan data pasien didalam komputer dan disempan di ruang rekam medik akan digunakan suatu saat oleh pasien bila berkunjung dipuskesmas untuk mendapatkan pelayanan kesehatan". 


\section{Pelayanan Pasien}

Petugas dalam pengurusan pelayanan data pasien yang dimaksudkan adalah dimana data pasien (status pasien) yang telah tersimpan di rekam medis akan dibawa oleh petugas ke poli yang akan dituju pada saat pasien berkunjung di puskesmas guna mendapatkan pelayanan medis, data status pasien sesudah selesai diproses divpoli yang dituju maka petugas akan mengambil data tersebut untuk disimpan kembali di ruang rekam medik dan didata lagi dalam 1 hari. Hal tersebut sesuai dengan kutipan wawancara sebagai berikut:

“ Iya,Petugaslah yang betugas mengantar data pasien yang telah disimpan direkam medik ke poli yang dituju, data akan diambil lagi oleh petugas setelah selesai pelayanan di poli dan akan didata lagi dalam 1 hari selsai".

\section{Keuangan}

Pasien diwajibkan membayar uang pendaftaran apabila pasien tidak memiliki kartu jaminan, hasil biaya pendaftaran pasien akan dibukukan oleh petugas untuk disetorkan dikasir setelah pelayanan pendaftaran pasien tidak dibuka atau jam tutup puskesmas. Sesuai kutipan wawancara sebagai berikut:

“ pasien wajib bayar uang pendaftaran apa bila pasien tidak memiliki kartu jaminan, nantinya uang pendaftaran akan disetor dikasir setelah pelayanan waktu loket sudah tutup".

Ini merupakan hasil wawancara mendalam dengan informan kunci 1 "T" dan 2 "I", merupakan petugas/pegawai pendaftaran pasien di Puskesmas Kecamatan Duren Sawit Jakarta Timur dan kemudian informan pendukung adalah pasien berjumlah sebanyak 2 orang informan pendukung "Z" dan "A".

Tabel 3 Matriks Hasil Wawancara dengan Informan Kunci 1, Informan Kunci 2 tentang Proses Pendaftaran di Puskesmas Kecamatan Duren Sawit Jakarta Timur

\begin{tabular}{|c|c|c|}
\hline $\begin{array}{c}\text { Komponen } \\
\text { Proses }\end{array}$ & Informan 1 & Informan 2 \\
\hline $\begin{array}{l}\text { Penerimaan } \\
\text { Pasien }\end{array}$ & $\begin{array}{ll}\text { - } & \text { Petugas } \\
\text { menpersiapakan } \\
\text { perlengkapan } \\
\text { pelayanan } \\
\text { pendaftaran } \\
\text { pasien terlebih } \\
\text { dahulu } \\
\text { - } \quad \text { Pasien datang }\end{array}$ & $\begin{array}{ll}\text { - } & \text { Mengarahkan } \\
\text { pasien untuk } \\
\text { melakukan } \\
\text { pendaftaran } \\
\text { - } \quad \text { Cek kartu } \\
\text { status pasien }\end{array}$ \\
\hline
\end{tabular}

\begin{tabular}{|c|c|c|}
\hline $\begin{array}{l}\text { Komponen } \\
\text { Proses }\end{array}$ & Informan 1 & Informan 2 \\
\hline & $\begin{array}{ll}\text { - } & \text { Pasien mendaftar } \\
\text { - } & \text { Diinformasikan } \\
\text { atau membantu } \\
\text { pasien yang } \\
\text { kurang mengerti } \\
\text { untuk memulai } \\
\text { pendaftaran. } \\
\text { - } & \text { Menunjukkan } \\
\text { kartu identitas } \\
\text { pasien baru atau } \\
\text { lama }\end{array}$ & \\
\hline $\begin{array}{l}\text { Pendaftaran } \\
\text { Pasien }\end{array}$ & 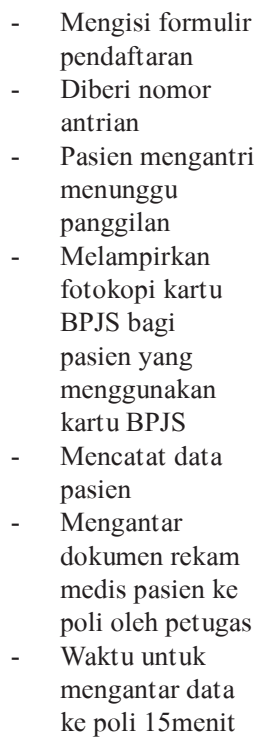 & $\begin{array}{ll}\text { - } & \text { Mengisi } \\
& \text { formulir } \\
\text { pendaftaran } \\
\text { - } & \text { Mengambil } \\
& \text { nomor antrian } \\
\text { - } & \text { Mencatat data } \\
& \text { pasien } \\
\text { - } & \text { Waktu untuk } \\
\text { pasien baru } \\
\text { kurang lebih } \\
15 \text { menit } \\
\text { - Pasien lama 5 } \\
\text { menit }\end{array}$ \\
\hline Adminitrasi & $\begin{array}{ll}\text { - } & \text { Menbayar di } \\
\text { loket pendaftaran } \\
\text { - } & \text { Menyimpan } \\
& \text { data pasien di } \\
\text { komputer } & \text { Pencatatan setiap } \\
\text { - } & \text { hari oleh semua } \\
\text { petugas } & \text { Poli umum Rp } \\
\text { 2000, MTBS Rp } \\
\text { 5000, Dokter } \\
\text { Umum Rp 15000 }\end{array}$ & $\begin{array}{ll}\text { - } & \text { Membayar } \\
\text { diloket } \\
\text { pendaftaran } \\
\text { - } & \text { Pakai } \\
\text { komputer } \\
\text { - } & \text { Pencatatan } \\
\text { setiap hari } \\
\text { oleh semua } \\
\text { petugas } \\
\text { diloket } \\
\text { pendaftaran }\end{array}$ \\
\hline
\end{tabular}

Tabel 4 Matriks Hasil Wawancara dengan Informan Pendukung tentang Proses Pendaftaran di Puskesmas Kecamatan Duren Sawit Jakarta Timur

\begin{tabular}{|c|c|c|}
\hline $\begin{array}{c}\text { Komponen } \\
\text { Proses }\end{array}$ & Informan 3 & Informan 4 \\
\hline $\begin{array}{l}\text { Penerimaan } \\
\text { Pasien }\end{array}$ & $\begin{array}{ll}\text { - } & \text { Datang, daftar, } \\
\text { isi formulir di } \\
\text { loket pendaftaran } \\
\text { - } & \text { Mendapatkan } \\
\text { nomor antrian } \\
\text { - } & \text { Bagan alur } \\
\text { pelyanan } \\
\text { pendaftaran tidak } \\
\text { ada }\end{array}$ & $\begin{array}{ll}\text { - } & \text { Mengisi formulir } \\
\text { - } & \text { pendaftaran } \\
\text { Menunggu } \\
\text { panggilan } \\
\text { nomor antrian } \\
\text { - } \quad \text { Tidak ada bagan } \\
\text { alur pendaftaran }\end{array}$ \\
\hline
\end{tabular}




\begin{tabular}{|c|c|c|}
\hline $\begin{array}{c}\text { Komponen } \\
\text { Proses }\end{array}$ & Informan 3 & Informan 4 \\
\hline $\begin{array}{l}\text { Pendaftaran } \\
\text { Pasien }\end{array}$ & $\begin{array}{ll}\text { - } & \text { Datang, isi } \\
\text { formulir } \\
\text { - } & \text { Diberi nomor } \\
\text { antrian } \\
\text { - } & \text { Antri } 5 \text { menit } \\
& \text { sampai 10menit }\end{array}$ & $\begin{array}{ll}\text { - } & \text { Mengisi formulir } \\
\text { pendaftaran } \\
\text { - } & \text { Menunggu } \\
\text { nomor pangilan } \\
10 \text { menit } \\
\text { - } \text { Mengantri sesuai } \\
\text { nomor, kecuali } \\
\text { ada nomor } 10 \\
\text { menit dipanggil, } \\
\text { dan tidak ada } \\
\text { pmberitahuan } \\
\text { akan dilewati } \\
\text { Cepat } 10 \text { menit }\end{array}$ \\
\hline Adminitrasi & 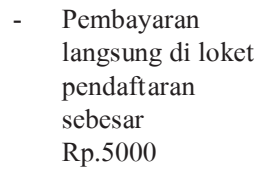 & $\begin{array}{ll}\text { - } & \text { Membayar } \\
\text { pendaftran } \\
\text { pasien } \\
\text { - } \quad \text { Biaya Rp. } 5000\end{array}$ \\
\hline
\end{tabular}

\section{Output}

Dari input dan proses yang telah terpapar diatas, maka dalam komponen output untuk melihat hasil keluaran atau proses pelayanan pendaftaran pasien. Proses output untuk mengetahui data pasien yang telah terdaftar di bagian pendaftaran pasien akan diproses. Semua data pasien yang tersimpan di rekam medis akan dibawa oleh petugas loket pendaftaran untuk diantarkan di bagian poli masing-masing. Setelah mendapatkan pelayanan medis maka pasing pulang.

\section{Telaah Dokumentasi}

Telaah dokumentasi merupakan teknik untuk pengumpulan data dan informasi saat penelitian langsung di lapangan, data dan informasi didapatkan secara langsung pada bagian pelayanan pendaftaran pasien di Puskesmas Kecamatan Duren Sawit Jakarta Timur. Data mengenai Sarana dan Prasarana pelayanan pendaftaran pasien dapat dilihat pada tabel dibawah ini:

\section{Tabel 5 Sarana dan Prasarana Pelayanan Pendaftaran Pasien di Loket Pendaftaran Puskesmas Kecamatan \\ Duren Sawit}

\begin{tabular}{|c|c|c|c|}
\hline No & $\begin{array}{l}\text { Kegiatan } \\
\text { Pelayanan } \\
\text { Pendaftaran }\end{array}$ & $\begin{array}{c}\text { Sarana dan } \\
\text { Prasarana }\end{array}$ & Ketersediaan \\
\hline 1. & $\begin{array}{l}\text { Pelayanan Awal } \\
\text { Pasien }\end{array}$ & $\begin{array}{ll}\text { 1. Alat peraga } \\
\text { 2. Buku register } \\
\text { 3. Kartu stat us } \\
\text { pasien } \\
\text { 4. Alat tulis }\end{array}$ & $\begin{array}{l}\text { Ada } \\
\text { Ada }\end{array}$ \\
\hline
\end{tabular}

\begin{tabular}{|c|c|c|c|}
\hline No & $\begin{array}{c}\text { Kegiatan } \\
\text { Pelayanan } \\
\text { Pendaftaran }\end{array}$ & $\begin{array}{c}\text { Sarana dan } \\
\text { Prasarana }\end{array}$ & Ketersediaan \\
\hline 2. & Pendaftaran Pasien & $\begin{array}{l}\text { Mengisi Formulir } \\
\text { Pendaftaran Baru } \\
\text { dan Lama }\end{array}$ & Ada \\
\hline 3. & Adminitrasi & $\begin{array}{ll}\text { 1. } & \text { Uang } \\
& \text { pendaftaran } \\
\text { 2. } & \text { Komputer } \\
\text { 3. } & \text { lemari (rak } \\
\text { status pasien) }\end{array}$ & $\begin{array}{l}\text { Ada } \\
\text { Ada } \\
\text { Ada }\end{array}$ \\
\hline 4. & Output & $\begin{array}{l}\text { 1. Data pasien } \\
\text { diantar } \\
\text { petugas ke } \\
\text { poli siap } \\
\text { mendapatkan } \\
\text { pelayanan } \\
\text { medis }\end{array}$ & Ada \\
\hline
\end{tabular}

Sumber : Puskesmas Kecamatan Duren Sawit

Sarana dan prasarana yang dibutuhkan dan digunakan petugas dalam melaksanakan pelayanan pendaftaran pasien sangat mendukung bagi petugas. Hal tersebut karena petugas memiliki tanggung jawab yang besar dalam pendataan dan menyimpan data pasien agar tidak menjadi kesalahan data pasien.

\section{SIMPULAN}

Berdasarkan hasil penelitian di Puskesmas Kecamatan Duren Sawit Jakarta Timur ini dapat ditarik keseimpulan:

1. Tata cara pemberian informasi di Puskesmas Kecamatan Duren Sawit sudah cukup baik yang telah dilakukan petugas untuk pelayanan pendaftaran pasien rawat jalan dan kepedulian petugas untuk membantu pasien yang masih kurang mengerti dalam pendaftaran pasien.

2. SDM atau petugas bekerjasama dengan baik dalam menangani pelayanan pendaftaran pasien, tidak saling ketergantungan dalam berkerja meski masih ada juga kinerja petugas yang relatif rendah dalam melayani pasien. Sarana yang menfasilitasi sudah cukup mendukung petugas untuk pelayanan pendaftaran pasien meski ada beberapa hal yang harus dibenahi.

3. Dalam proses penerimaan pasien di Puskesmas Kecamatan Duren Sawit cukup baik, pasien pasti diarahkan untuk mengisi formulir pendaftaran dan menunjukan kartu identitas pasien.

4. Dalam proses sistem pendaftaran pasien rawat jalan di Puskesmas Kecamatan Duren Sawit masih kurang baik. Tidak ada alur khusus pasien mengantri dengan tertib dan kekonsistenan 
petugas dalam mengambil kartu status rekam medis pasien untuk mendapatkan pelayanan kesehatan dan masih sering tidak sesuai nomor antrian.

5. Dalam pengadminitrasian pendaftaran pasien rawat jalan di puskesmas cukup baik untuk pelayanan pendaftaran pasien.

\section{DAFTAR PUSTAKA}

Adisasmito, Wiku. (2007). Sistem Kesehatan. Jakarta: Raja Grafindo Persada.

Azwar, Azrul. (2010). Pengantar Adminitrasi Kesehatan, Edisi Ketiga. Jakarta: PT. Bina Rupa Akarsa.

Handoko. (2003). Manajemen. Yogyakarta: BPEE.

Munijaya, AA Gde. (2012). Manajemen Kesehatan. Jakarta: EGC

Siagian, Sondang. (2008). Manajemen Sumber Daya Manusia. Jakarta: Bumi Aksara.
Siswanto. (2005). Pengantar Manajemen. Jakarta: Bumi Aksara.

Sugiyono. (2012). Metode Penelitian Kualitatif dan $R \& D$. Jakarta: CV . Alfabeta.

Sutejo B. (2002). Perencanaan dan Pembagunan Sistem Informasi. Yogyakarta: Andi Offset.

Jogiyanto HM. (2005). Analisis \& Desain Sistem Informasi: Pendekatan Tertruktur Teori dan Praktek Aplikasi Bisnis. Yogyakarta: Andi.

Imron; Munif, A. (2010). Metodologi Penelitian Kesehatan. Jakarta: Rineka Cipta.

Notoatmodjo, Soekidjo. (2005). Metodologi Penelitian Masyarakat. Jakarta: Rineka Cipta.

Riyanto, Agus. (2010). Pengolahan dan Analisis Data Kesehatan. Yogyakarta: Nuha Medika.

Trihono. (2005). Manajemen Puskesmas. Jakarta: Sagung Seto 